\title{
Development of Assessment of Music Perception for the Hearing-impaired
}

\author{
Yerim Shin ${ }^{1}$, Jiyeong Yun ${ }^{1}$, Jeong-Sug Kyong ${ }^{2}$, Sungmin Jo ${ }^{1}$, Jinsook Kim ${ }^{1,3}$ \\ ${ }^{1}$ Department of Speech Pathology and Audiology, Graduate School, Hallym University, Chuncheon, Korea \\ 2Department of Audiology and Speech-Language Pathology, Hallym University of Graduate Studies, Seoul, Korea \\ ${ }^{3}$ Division of Speech Pathology and Audiology, Research Institute of Audiology and Speech Pathology, College of Natural Sciences, Hallym University, \\ Chuncheon, Korea
}

Received: July 10, 2021

Revised: September 28, 2021

Accepted: October 16, 2021

Correspondence:

Jinsook Kim, PhD

Department of Speech Pathology

and Audiology, Graduate School,

Hallym University, 1 Hallymdaehak-

gil, Chuncheon 24252, Korea

Tel: +-82-33-248-2213

Fax: +82-33-256-3420

E-mail: jskim@hallym.ac.kr

\begin{abstract}
Purpose: Enhancement of musical perception has a positive impact on the emotional stability, quality of life, and aural rehabilitation in individuals with hearing loss. In Korea, however, there are a few test batteries available for properly assessing their abilities to perceive music. The purpose of this study was to develop a evaluation material for the music perception ability, Assessment of Music Perception (AMP) considering the Korean culture and emotion. Methods: A total of 15 normal hearing adults (33.1 \pm 11.4 years) were recruited. They performed the AMP which includes eight sub-tests: pitch, melody, rhythm, timbre, and harmony perception test, emotional reaction test, Music listening Attitudes and Satisfaction Questionnaire (MASQ), and Mismatch negativity (MMN). Results: The average percentage of correct answer was $94.0 \% \pm 6.1 \%$ in pitch perception test, $94.0 \% \pm 7.1 \%$ in melody perception test, $99.3 \% \pm 1.8 \%$ in rhythm perception test, $78.9 \% \pm 41.8 \%$ in timbre perception test, $96.7 \% \pm 10.4 \%$ in emotional reaction test, $85.7 \% \pm 14.1 \%$ in harmony perception test. The area of the negative waveform for MMN was $275.27 \pm 225.65 \mu \mathrm{V} \cdot \mathrm{ms}$ with the intensity of $70 \mathrm{dBnHL}$. Conclusion: Considering high scores of a instrument, a developed AMP could be applied for evaluating the music perception ability. However, a little bit of correction for each factor of materials is recommended for comprehensive AMP material. In the future, the music perception ability of the hearing impaired should be evaluated utilizing AMP.
\end{abstract}

Key Words: Assessment of music perception (AMP), Pitch perception test, Melody perception test, Timbre perception test, Mismatch negativity (MMN).

\section{INTRODUCTION}

음악은 사전적으로 "박자, 가락, 음성 따위를 갖가지 형식으로 조화하고 결합하여, 목소리나 악기를 통하여 사상이나 감정을 나타내는 예술”로 정의된다. 그러나 이러한 정의는 해당 시대나 민족이 어떠한 형식으로 음악을 표현하는지에 따라서 다양한 양 상과 독특한 형태로 나타난다(Han, 1991). 더욱이 음악은 웃기, 울기, 전율, 가슴 벅참 등과 같은 강한 정서적 반응을 유발하거나 종교적, 정치적, 사회적 의사소통도구로 사용되어 왔다. 또한 최 근에는 음악 활용의 문화적 범위가 확대되어 심리치료 및 복지 증진의 목적으로도 사용되고 있다.

(c) This is an Open Access article distributed under the terms of the Creative Commons Attribution Non-Commercial License (https://creativecommons.org/ licenses/by-nc/4.0) which permits unrestricted non-commercial use, distribution, and reproduction in any medium, provided the original work is properly cited.
음악지각능력은 리듬(rhythm), 피치(pitch), 화음 (harmony), 음색(timbre) 등의 기본 음향적 요소를 분석할 수 있는 능력과 불협화음과 협화음의 구별, 멜로디에 사용된 악기의 수를 파악하는 능력, 음악에 실린 정서를 동감하는 능 력, 언어능력, 음악인지와 관련된 개별적 상황 등에 따라 달라 질 수 있다. 그중 리듬은 흐름이나 움직임을 뜻하는 리트머스 (rhythmos)에서 유래된 단어로 신체적 운동, 심리적, 생리적 작 용과 연관될 수 있지만 음악에서는 초나 분 단위의 시간적 요소 와 관련되어 음표의 길고 짧음, 음의 셈여림과 빠르기 등에 따 라 반복되는 일정한 음의 흐름을 의미한다(Jeong \& Lee, 2012; Yoon, et al., 2006). 피치(pitch)란 음고라고도 불리는데 음의 높낮이의 높고 낮음을 심리음향학적으로 표현한 음악의 한 요소 이다. 두 개 이상의 피치가 연속적으로 이어지고 체계적으로 구 성되면 가락 또는 선율이라고도 불리는 멜로디(melody)가 되는 
데 멜로디는 사람들의 선호도에 따라 달라져서 그 시대의 특성 과 민족 고유의 정서를 나타내기도 한다. 화음은 높이가 다른 두 개 이상의 음이 함께 어울릴 때 나타나는 소리의 특성으로 일반 적으로 협화음과 불협화음으로 나뉜다(Sim, 1996). 같은 화음 을 들어도 듣는 주체에 따라 협화음으로 들릴 수도 있고 불협화 음으로 들릴 수도 있는데 이는 동시에 들리는 소리가 서로 어울 리는 것으로 들리는지 혹은 부딪히는 소리로 들리는지를 판단 하는 주관적 개념이 포함되기 때문이다. 음색은 음을 만드는 구 성요소의 차이로 생기는 소리의 감각적인 특색을 뜻하는데, 악 기에서 진동수의 많고 적음, 진동 길이의 길고 짧음, 진동시키는 방법 등에 의해 특정 음색으로 나타난다. 또한, 사람의 음색은 특정 사람의 음성으로 구별하게 하는 요소가 될 수 있다(Lee, 2013).

인간의 청각 체계는 음악적 신호를 기저막의 특정 지점의 대역 통과(band-pass) 필터에 근거하여 분석하여 인지하기 때문에 정상 청력은 음악 청취에 필수적이다(Moore, 2008). 그러나 청 력손실이 있으면 청각 필터의 기능이 불충분하고 미세한 시간분 석능력과 주파수선별능력도 감소하여 음악분석능력이 정상일 수 없다(Looi et al., 2008). 또한 음악의 정서적인 인지도 어려 움을 보인다(Gottselig, 2001). 청각장애인의 음악지각능력 향 상을 위해서는 어느 정도의 수준인지 정확하게 평가하는 도구가 필요하다. 특히 건청인과 청각장애인의 음악지각능력을 구체적 으로 분석하는 도구가 필요하다. 더 나아가 건청인들의 음악지각 능력과 개인적 차이를 제대로 확인하여야 청각장애인의 능력과 비교할 수 있다. 이를 토대로 청각장애인의 음악지각능력을 향상 시킬 수 있는 음악재활도구가 개발되어야 한다. 현재까지 연구된 국내외 음악지각능력 평가도구를 살펴보면 다음과 같다.

해외의 음악지각능력 평가도구는 The Musical Aptitude Profile (MAP; Gordon, 1967)로 시작되었다. MAP는 초등학 교 4학년부터 성인을 대상으로 음감과 리듬감 영역을 포함하 는 비선호도검사와 음악적 감수성 영역을 포함하는 선호도검사 로 구성되는데, 이 도구는 3시간 정도의 오랜 시간이 소요되는 단점이 있다. 이를 우리나라에서 실시하여 그 적용 가능성을 실 험한 결과 한국 음악에 대한 성취도는 잘 예견하지 못한다는 한 계가 보고되어 이 또한 현실적 활용을 어렵게 하는 단점으로 지 적되었다(Hyun, 2000). Gordon(1979)이 개발한 또 다른 검 사인 Primary Measures of Music Audiation은 5 8세 아동 을 대상으로 하는 표준화된 음악적성검사로, 글과 숫자를 몰라 도 쉽게 평가할 수 있도록 짧은 음악적 소절들로 이루어진 음정 과 리듬검사로 구성된 장점이 있으나 개발된 시점이 너무 오래되 어 현실적으로 검사로 사용하기에는 한계가 있다. 인공와우 착 용자의 음악청취능력을 평가하기 위해 개발된 Musical Sounds in Cochlear Implants (Fitzgerald et al., 2006)는 리듬, 피
치, 멜로디, 화음 등의 기본적인 음향학적 요소 외에 악기의 수, 악기의 명칭, 불협화음의 정도, 음악과 관련된 감정 등을 평가하 는 검사로 음악의 다양한 요소들을 포함하여 구성되어 있는 장 점이 있으나 인공와우 착용자 만을 대상으로 하는 단점이 있다. University of Washington's Clinical Assessment of Music Perception (UW-CAMP; Kang et al., 2009)은 영어를 모국 어로 하는 성인 인공와우 착용자를 위해 개발된 도구로 피치, 멜 로디, 음색인지검사로 구성되어 있어 널리 사용되고 국내에서도 해석본이 나올 만큼 우수한 검사이다. Music Perception Test (MPT; Uys \& van Dijk, 2011)는 남아프리카의 보청기 착용자 를 위해 개발된 음악지각능력 평가도구로 리듬, 음색, 피치, 멜로 디검사로 구성되어 있는데, 해당 검사의 난이도와 사용된 자극 음에 대한 만족도를 묻는 설문지도 포함되어 있다. 그러나 MPT 는 남아프리카에서 오랫동안 생활한 사람이 아니라면 검사에 사용된 자극음에 대한 친숙도가 떨어지고, MPT에서의 수행력 이 전반적인 음악적 만족도를 의미한다고 할 수 없다는 단점이 있다. 9세 이하의 인공와우 착용 아동을 위해 리듬, 피치, 멜로 디, 하모니, 음색인지검사로 구성되어 있는 Music in Children with Cochlear Implants (Roy et al., 2014)는 제시되는 두 개 의 자극이 동일한지 혹은 동일하지 않은지 구별하는 아주 간단 한 검사도구여서 자극 자체를 정확하게 인지하였는지 여부는 알 수 없는 단점이 있다.

이러한 주관적 검사뿐만 아니라 객관적 검사도 음악지각능력 평가에 사용되었다. Mismatch negativity (MMN)반응은 전 주의적 단계의 청각 처리 과정과 관련된 전기생리학적 반응인데, 선행 연구에서는 멜로디의 양상과 미세한 피치의 변화를 상위 수준에서 자동적으로 인지할 수 있는지 확인한 선행 연구가 있 다. 그 연구에서는 4년 이상 음악 교육을 받은 경험이 없는 비전 문가 정상 청력 집단을 대상으로 멜로디 패턴의 변화가 있을 때 와 멜로디를 구성하는 피치의 변화가 있을 때로 자극음을 각각 구성하여 MMN반응검사를 실시하였다. 그 결과 두 자극음 조 건에서 모두 유의미한 $\mathrm{MMN}$ 반응이 나타나 비전문가이지만 정 상 청력인이 피치의 정확한 주파수 정보를 청각 피질에서 인지할 수 있음을 확인하였다(Trainor, 2002). 또한 정상 청력 그룹과 인공와우 착용 그룹을 대상으로도 클라리넷 소리를 주파수, 강 도, 지속시간(duration)을 제시하여 MMN반응을 분석한 연구 에서는, 인공와우 착용 그룹이 적은 $\mathrm{MMN}$ 진폭을 보이고 청각적 인 구별능력의 정확도와 민감도가 떨어지고 뇌활동이 제한적이 라고 보고하였다(Sandmann et al., 2010). 더 나아가 MMN반 응검사를 음악 전문가와 비전문가 그룹에게 실시하여 음악 훈련 및 경험의 차이를 분석하였을 때, 음악 전문가 그룹은 비전문가 그룹보다 유의미하게 더 넓은 $\mathrm{MMN}$ 면적을 보여 음악 교육 경험 이 청각 정보의 변화를 자동적으로 인지하는 능력을 강화시키는 
점을 확인하였다(Fujioka et al., 2004). 이러한 음악 전문가의 강화된 능력은 전주의적 단계에서 음악 관련 자극의 정보를 더 잘 추출하기 때문인 것으로 보고되었다(Koelsch et al., 1999). 또한 음악 전문가의 청각시스템은 집중하지 않아도 많은 음악의 규칙적인 패턴을 해석할 수 있는 능력이 있는 것으로 나타났는 데(Van Zuijen et al., 2005) 약 4\%의 주파수 차이가 있는 자극 음의 피치분별에 대한 음악 전문가와 비전문가의 차이는 청각사 건관련전위(auditory event related potential)평가로는 분석 할 수 있었으나 MMN평가로는 분석할 수 없었다(Tervaniemi et al., 2005). MMN자극음으로 음성을 사용한 연구에서는 고 음 음성이 저음 음성보다 더 현저히 지각되는 음성으로 나타나 서 음조에 따라 기억흔적이 달라지는 점도 확인하였다(Fujioka et al., 2005).

국내에서 개발된 음악지각검사도구도 여러 개 있다. 한 쌍의 리듬패턴과 가락패턴을 듣고 같은지 다른지를 구별하는 간단 한 검사인 한국음악적성검사(Korean Music Aptitude Test, KMAT) (Hyun, 2000)는 9살 이상의 일반 학생들을 대상으로 서양 음악과 국악을 이용한 리듬검사와 가락검사로 구성되어 있 다. 또한 언급한 UW-CAMP를 한국 성인 인공와우 착용자를 위 해 한국어로 번역한 검사도구인 Korean version of Clinical Assessment of Music Perception (K-CAMP; Jung et al., 2010)은 멜로디검사에 '나비야', '아리랑', '퐁당퐁당'과 같은 국 내의 동요와 민요를 포함하였다. 12 명의 인공와우 착용자와 12 명 의 정상 청력 성인을 대상으로 평가하였을 때 인공와우 착용그 룹은 모든 하위검사에서 정상 청력 그룹보다 낮은 정답률을 보였 다. UW-CAMP검사 결과와 비교하였을 때 멜로디검사는 비슷 한 정답률을 보였으나 음색검사는 $\mathrm{K}-\mathrm{CAMP}$ 검사에서 인공와우 착용자와 정상 청력 그룹 모두 낮은 정답률을 보였는데 이는 서 양악기에 대한 경험이 부족한 것으로 저자들은 설명하고 있다.

음악지각능력을 평가하는 설문지도 있다. 해외의 경우 $\mathrm{Mu}-$ nich Music (Brockmeier, 2000)은 언어습득 후 인공와우를 착용한 경우의 음악 감상 습관을 기록하기 위한 설문지로 음악 감상하기, 악기 연주하기, 노래 부르기 활동에 대해 청력손실이 시작되기 전, 인공와우 이식을 하기 전, 인공와우 이식을 한 후로 나누어 평가할 수 있도록 구성하였다. 그 외 음악과 상호작용을 측정하기 위해 자기보고 형식으로 제작된 설문지인 Music USE (Chin \& Rickard, 2012), ‘음악 교육 및 활동 경험에 따른 음악 감상 만족도 설문지'(Kwon, 2019), '중·고등학생의 음악 선호도 및 활동 실태 설문지'(Ryu, 2014) 등이 있다.

이렇게 많은 평가지의 개발에서도 보여주듯이, 청각장애인의 음악지각능력을 향상시키기 위해서는 청각장애인의 음악지각능 력에 대한 정확한 평가가 우선되어야 한다. 따라서 음악지각능 력을 구체적이고 체계적으로 분석하고 평가하여 음악지각능력
을 정량화할 수 있는 도구가 필요한데, 선행 논문을 분석하여 정 리하면 약 세 가지 분야의 평가도구로 요약할 수 있다. 첫째, 음 악의 기본요소별 평가로 구성된 주관적 검사이다. 현재까지 개발 된 선행 음악지각검사는 대부분 해외에서 제작된 검사를 해석하 여 사용하였으므로 국악기 등이 포함된 검사는 없었다. 이를 반 영하고 음악이 민족 고유의 문화와 정서를 반영하는 것을 고려 하여 한국 고유의 음악을 포함하는 평가도구가 필요하다. 청각 장애인을 대상으로 음악검사를 실시하려면, 청각장애인의 특수 한 환경을 이해하고 청각장애의 음악지각 특성과 수준을 고려한 검사가 필요하다. 따라서 소리의 주파수구별능력을 확인하는 피 치검사, 한국의 문화와 정서를 반영하는 멜로디인지능력을 확인 하는 멜로디검사, 여러 가지 유사한 리듬의 구별능력을 확인하 는 리듬검사, 주변 환경에서 쉽게 접할 수 있는 우리나라 고유의 민속 악기를 포함하여 다양한 악기 소리의 구별능력을 확인하는 음색검사, 음악에서 느껴지는 분위기와 정서를 파악하는 능력을 확인하는 감정반응검사, 화음과 불협화음의 구별능력을 확인하 는 화음검사로 이루어진 음악지각검사를 개발하였다. 또한 청각 장애인을 대상으로 검사하기 위해서 시각적인 자료로 검사에 대 한 안내를 제시하고, 컴퓨터 화면을 이용하여 반응 내용을 표현 할 수 있도록 하는 것이 중요하고, 청각장애의 음악지각 수준을 고려하여 비교적 쉬운 검사 방법이 제시되어야 할 것이다. 둘째, 주관적인 음악지각검사의 정량화된 결과를 소리 자극에 대한 단 기 기억 흔적을 객관적으로 평가하여 비교할 수 있는 객관적 검 사, 즉 $\mathrm{MMN}$ 검사로 음악지각능력 평가 결과를 객관적으로 분석 하여 주관적 음악지각능력이 객관적 뇌 인지 활동에 어느 정도 반영되는지 확인하여야 한다. 셋째, 정상인과 청각장애인의 보 장구를 사용한 음악 감상 만족도 등을 파악하여 음악 감상에 대 한 태도 및 습관을 확인할 수 있는 질문으로 구성된 설문지가 필 요하다. 현재 개발된 설문지 중 국외 설문지는 음악 감상 및 습 관의 문화적 차이가 있어 적용하기에 어려움이 있다. 국내 설문 지는 음악 교육 또는 경험에 따른 음악 감상 만족도를 중심으로 제작된 설문지이거나 청소년을 대상으로 하는 간단한 설문지이 기 때문에 일반적으로 청각장애인이 보장구를 통한 음악 감상의 만족도나 감상 태도를 분석할 수 있는 설문지 개발이 필요하다. 따라서 이러한 내용을 포함한 종합적 음악지각검사도구로 건청 과 청각장애가 있는 경우에 모두 적용이 가능하고, 음악지각능 력을 구체적이고 체계적으로 음악 구성요소별 지각능력을 확인 할 수 있는 음악지각검사(Assessment of Music Perception, $\mathrm{AMP}$ )를 개발하고자 한다. 우리나라의 음악 정서를 반영하고 음 악지각능력을 종합적으로 평가하여 음악지각능력에 대한 이해 도를 높이고 청각장애가 있는 경우 평가 결과에 따라 맞춤형으 로 음악감상을 선택하여 재활하고 훈련할 수 있는 프로그램으로 $\mathrm{AMP}$ 를 제작하고자 한다. 결론적으로 $\mathrm{AMP}$ 를 통해 음악지각능 
력의 기초 자료를 제공하여 청각장애인이 음악을 접할 수 있는 기회를 확대하고, 정서적 안정과 삶의 질 향상을 위해 음악을 활 용할 수 있고, 청능 훈련의 효과도 향상시키고, 청각시스템의 뇌 가소성도 활성화시킬 수 있도록 기여하고자 한다.

\section{MATERIALS AND METHODS}

피치지각검사, 멜로디지각검사, 리듬지각검사, 음색지각검사, 감정반응검사, 화음지각검사, $\mathrm{MMN}$, 음악감상태도 및 만족도 설문지(Music listening Attitudes and Satisfaction Questionnaire, MASQ) 등 9개 검사도구로 AMP를 개발하였다.

\section{연구 대상 및 절차}

$\mathrm{AMP}$ 의 초기 구성을 위해 20 대 건청 성인 남성 5 명과 여성 5 명 (26.1 \pm 2.3 세)을 대상으로 예비검사를 실시하였다. 예비검사 는 친숙한 멜로디와 악기를 선정하고 노래의 감정을 확인하기 위 해 멜로디, 음색지각검사, 감정반응검사의 개발에 적용하였다. 예비검사 결과 정답률이 높은 멜로디와 악기를 최종 문항으로 선정하였다. 정답률이 같아 동점일 경우와 친숙도가 높은 멜로 디와 악기를 선정하기 위해 대학원생들로 구성된 연구자문단에 게 질문하여 답변 내용을 분석하였다. 이를 청각학 전공 교수 1 명 과 연구를 진행하는 석사과정 대학원생 2 명이 심도 있는 논의로 최종 도구를 선정하였다. 그 후 완성된 $\mathrm{AMP}$ 를 15 명의 정상 청 력인을 대상으로 검사하여 검사도구로 활용 가능성을 확인하였 다. 본 연구에 대한 모든 절차 및 내용은 한림대학교 생명윤리위 원회(Institutional Review Board, IRB)로부터 승인을 받았다 (승인번호 HIRB-2019-070). 모든 대상자의 평균 연령은 33.1 \pm 11.4 세였으며, 남성은 9명(35.0 \pm 11.0세), 여성은 6명(30.3 \pm 12.3 세)이었다. 피검자는 순음청력검사 결과에서 250 8,000 $\mathrm{Hz}$ 에서 모두 $20 \mathrm{~dB}$ 미만의 정상 청력역치를 보였고 어음인지역 치(speech reception threshold)는 우측 귀는 $5.0 \pm 4.2 \mathrm{~dB}$ $\mathrm{HL}$, 좌측 귀는 $1.7 \pm 5.2 \mathrm{~dB}$ HL이었다. 피검자가 가장 편안하 게 들리는 강도에서 어음인지도(word recognition score)를 측 정한 결과, 우측 귀는 $48.3 \mathrm{~dB} \mathrm{HL}$ 에서 $98.9 \% \pm 2.4 \%$, 좌측 귀 는 $46.7 \mathrm{~dB} \mathrm{HL}$ 에서 $99.5 \% \pm 1.4 \%$ 였다.

\section{연구 방법}

예비검사를 포함한 모든 검사는 방음실에서 진행되었으 며 순음청력검사와 어음검사는 GSI 61 (Granson-Stadler; Eden Prairie, MN, USA) 청력검사기와 헤드폰(TDH-50 Telephonics Corporation, Farmingdale, NY, USA)을 사용 하여 진행하였다. AMP는 태블릿 PC (Surface pro 6; Microsoft, Redmond, WA, USA)로 진행하였다. 내장된 Super Lab
5.0 (Cedrus, San Pedro, CA, USA) 프로그램을 통해 스피커 로 자극음을 $75 \mathrm{~dB} \mathrm{SPL}$ 제시하여 반응을 수집하였다.

\section{통계 분석}

수집된 자료 분석에는 SPSS 프로그램(version 25; IBM Corporation, Armonk, NY, USA)을 이용하였다. 대상자의 피치, 멜로디, 리듬, 음색, 화음지각, 감정반응검사 항목별 비교 를 위해 일원분산분석(one-way analysis of variance)을 사 용하였다. 또한 각 검사항목 내 구성요소인 각각의 주파수 및 주 파수 대역, 멜로디 종류, 리듬패턴, 악기 종류, 화음 종류, 곡 종 류에 따른 지각능력 차이를 알아보고자 대응표본 $t$ 검정(paired $t$-test)을 사용하여 분석하였다. 모든 통계 분석의 유의미 수준 은 $p<0.05$ 로 설정하였다.

\section{$\mathrm{AMP}$ 개발}

\section{피치지각검사}

저주파수와 고주파수 소리의 구별 능력을 확인하기 위하여 Noteworthy composer (ver. 2.75; Noteworthy Software, Inc., Valdese, NC, USA)를 통해 제작된 6개의 다른 주파수 로 이루어진 순음으로 피치지각검사를 구성하였다. 저주파수 대 역 자극음으로는 음 구성에 기준음으로 자주 사용되는 C4 $(262$ $\mathrm{Hz}), \mathrm{C} 4$ 보다 3도 높은 $\mathrm{E} 4(330 \mathrm{~Hz}), \mathrm{E} 4$ 보다 3도 높은 G4 $(392$ $\mathrm{Hz})$ 를 선정하였다. 고주파수 대역 자극음으로는 각 저주파수 대 역 자극음보다 두 옥타브 위인 C6 $(1,047 \mathrm{~Hz}), \mathrm{E} 6(1,319 \mathrm{~Hz})$, G6 $(1,568 \mathrm{~Hz})$ 를 선정하였으며 모든 자극음은 100 beats per minute $(\mathrm{bpm})$ 의 빠르기와 2 분음표의 길이로 제작하였다. 검 사의 진행은 여섯 개 순음 중 두 개를 $1,000 \mathrm{~ms}$ 의 자극 간 간격 (inter-stimulus interval, ISI)을 두어 무작위순으로 들려준 후 처음에 제시된 소리와 나중에 제시된 소리 중 더 높은 소리 혹은 더 낮은 소리를 선택하도록 하였다. 검사를 실시하기 전에 두 번 의 연습 기회를 제공하였고 6 개 피치로 만들 수 있는 모든 경우 의 15개 세트(C4-E4, G4, C6, E6, G6 / E4-G4, C6, E6, G6 / G4-C6, E6, G6 / C6-E6, G6 / E6-G6)를 앞-뒤 자극의 순서 를 바꾸어 2회 제시하여 총 30 개 문항으로 구성하였다(Appen$\operatorname{dix} 1)$.

\section{멜로디지각검사}

예비검사는 한국인의 정서와 문화를 반영하여 음악장르의 구 분 없이 한국인에게 친숙한 멜로디 12 개, '고향의 봄', '까치까치 설날은, '나비야, ‘루돌프 사슴코', '산토끼', '새타령', '생일축하 합니다', '섬집아기', '아기염소', '아리랑', '작은별', '푸른하늘 은 하수를 자극음으로 사용하였다. 자극음은 곡의 가장 익숙한 멜 
로디 부분을 선택하여 해당 곡의 특성을 보여줄 수 있는 4 5마 디로 구성하였고, 비슷한 음계 범위인 C4 C5 사이로 음의 높 낮이를 조정하였다. 대상자가 멜로디에만 집중하여 검사를 하도 록 리듬 단서를 제거하고 Noteworthy composer를 통해 120 $\mathrm{bpm}$ 의 빠르기와 4 분음표의 길이로 제작하였다.

예비검사 결과, 평균 정답률은 $94.0 \% \pm 7.1 \%$ 였는데 '생일축 하합니다', '섬집아기', '작은별'에서 $100 \%$ 로 가장 높은 정답률을 보였고, '고향의 봄'에서 $80 \%$ 로 가장 낮은 정답률을 보였다. 따 라서 $80 \%$ 미만으로 나온 '산토끼’와 ‘아기염소를 제외하고 총 10 개 의 멜로디로 검사를 최종 구성하였다. 최종적으로 구성된 멜로디 지각검사의 진행은 검사 전 모든 멜로디를 한 번씩 들려주어 멜 로디와 곡의 제목을 매칭하며 친숙하게 한 후 10 개 멜로디가 2회 반복 제시되어 총 20 개 문항을 무작위 순서로 들려준 후 해당하 는 곡의 제목을 선택하도록 하였다(Appendix 1).

\section{리듬지각검사}

리듬지각검사의 자극음을 Linux Multi Media Studio (https://lmms.io/)를 통해 다섯 개의 리듬패턴으로 구성하여 유사하지만 서로 다른 리듬의 특성을 구별할 수 있는지 확인하 고자 하였다. 모든 자극음은 한 마디에 8 분음표 네 개와 8 분심 표 네 개로 이루어진 스네어 드럼 소리로 $120 \mathrm{bpm}$ 의 빠르기와 $4 / 4$ 박자의 길이로 제작하여 다섯 개의 리듬패턴을 $\mathrm{A}, \mathrm{B}, \mathrm{C}, \mathrm{D}$, $\mathrm{E}$ 로 명명하였다. 리듬패턴 $\mathrm{A}$ 는 네 개의 음표와 네 개의 쉼표가 한 번씩 번갈아 반복되는 기본적인 리듬으로 음표-쉼표-음표쉼표-음표-쉼표-음표-쉼표의 형태로, 리듬패턴 B는 음표-쉼표음표-쉼표-음표-쉼표-쉼표-음표의 형태로, 리듬패턴 $\mathrm{C}$ 는 음 표-쉼표-음표-쉼표-음표-음표-쉼표-쉼표의 형태로, 리듬패턴 $\mathrm{D}$ 는 음표-쉼표-음표-음표-음표-쉼표-쉼표-쉼표의 형태로, 리 듬패턴 $\mathrm{E}$ 는 음표-쉼표-쉼표-음표-음표-쉼표-쉼표-음표의 형태 로 구성하였다. 이렇게 완성된 다섯 개 리듬패턴 중 두 개의 패턴 을 들려준 후, 두 개 패턴이 동일한지 여부를 확인하도록 하였다. 모든 리듬패턴은 음표와 쉼표로 이루어져 있어 ISI를 짧게 주었 을 경우 쉼표와 혼돈할 수 있어 다른 검사에 사용된 ISI보다 조 금 긴 3,500 ms로 설정하였다. 검사를 실시하기 전 연습 기회를 두 번 제공하였으며, 10 개 세트, 정답이 '같다'인 문항 5 개, $\mathrm{A}-\mathrm{A}$, $\mathrm{B}-\mathrm{B}, \mathrm{C}-\mathrm{C}, \mathrm{D}-\mathrm{D}, \mathrm{E}-\mathrm{E}$ 와 정답이 '다르다'인 문항 5 개, A-B, B-C, $\mathrm{C}-\mathrm{D}, \mathrm{D}-\mathrm{E}, \mathrm{E}-\mathrm{A}$ 를 2회 제시하여 총 20 개 문항으로 구성하였다 (Appendix 1).

\section{음색지각검사}

예비검사는 서양 악기와 국악기에서 악기 종류별로 대표적이 고 친숙한 후보 악기 3개씩 구성하여 각 악기마다 고유한 소리 구별능력을 확인하고 그중 적절한 악기를 선정하기 위해 진행하
였다. 또한 선행 연구(Kang et al., 2009)의 음색지각검사 구성 을 참조하여 대상자가 악기 소리를 찾는 데에만 집중할 수 있도 록 자극음을 예측이 불가능한 다섯 음계인 C4-A4-F4-G4-C5 를 연주한 소리를 자극음으로 제시하였으므로 해당 음계를 연주 할 수 있는 악기로 후보 악기를 구성하였다. 또한 베이스 드럼, 팀 파니, 꽹과리, 장구, 징처럼 타악기의 경우 악기 특성 상 C4 C5 의 범위를 연주할 수 없어도 음색의 특성을 충분히 일관되게 제 시할 수 있기 때문에 포함시켰다. 이러한 기준으로 구성한 후보 악기는 서양 악기에서는 금관 악기는 트럼펫, 트롬본, 호른, 목 관 악기는 오보에, 클라리넷, 플룻, 현악기는 바이올린, 비올라, 첼로, 타악기는 베이스 드럼, 실로폰, 팀파니였다. 또한 일상에 서 접하기 쉬운 익숙한 악기로 일반적으로 초, 중, 고등학교 과 정에서 자주 접하는 현악기인 기타, 관악기인 리코더, 건반악기 인 피아노를 기타 악기로 구분지어 총 15 개의 후보 악기를 선정 하였다. 국악기에서는 현악기는 가야금, 아쟁, 해금, 관악기는 대 금, 향피리, 타악기는 꽹과리, 장구, 징으로 총 8개의 후보 악기 를 선정하였다. 서양 악기 중 베이스 드럼, 팀파니, 리코더, 피아 노 소리는 Noteworthy composer를 통해, 나머지 악기 소리는 Bandlab (https://www.bandlab.com/)을 통해 120 bpm의 빠르기와 4 분음표의 길이로 음원을 제작하였다. 국악기 중 꽹과 리와 징 소리는 '국립국악원 국악기 디지털 음원'(http://www. gugak.go.kr/site/main/index001)을 이용하여, 나머지 악기 소리는 '서울대학교 예술과학센터 국악 가상 악기 음원 라이브 러리'(http://www.catsnu. com/Main/Main.aspx)를 이용하 여 $90 \mathrm{bpm}$ 의 빠르기와 4분음표의 길이로 음원을 제작하였다. 국악기 중 징은 서양 악기와 동일한 템포인 $120 \mathrm{bpm}$ 으로는 여 운이 길고 울림이 깊은 특성을 표현하기에 너무 빠르므로 비교적 느린 템포인 $90 \mathrm{bpm}$ 으로 선정하였다. 실로폰을 제외한 모든 서 양 악기와 국악기의 타악기는 서로 다른 음계 다섯 개를 제시하 는 것이 어려우므로 동일한 박자를 다섯 번 반복 연주한 자극음 으로 제작하였다.

예비검사 결과, 악기 분류별로 정답률이 낮은 악기 하나씩을 제외하고 서양 악기 10 개, 국악기 6 개, 총 16 개의 악기로 최종 구성하였다. 서양 악기의 경우, 현악기에서 바이올린이 $75 \%$, 비 올라와 첼로가 $55 \%$ 의 정답률을 보였는데 바이올린과 비올라의 음색이 매우 유사하므로 난이도 조절을 위해 바이올린보다 비 교적 친숙도가 낮은 비올라를 제외하였다. 국악기의 경우, 관악 기에서는 대금이 $87.5 \%$, 향피리가 $45 \%$ 의 정답률을 보였으나 악 기의 수가 처음부터 두 개 밖에 되지 않아 모두 최종 악기로 포 함하였다. 타악기에서는 꽹과리, 장구, 징이 모두 $100 \%$ 의 정답 률을 보였는데 긴 여운을 가지는 소리를 특징으로 하는 징은 검 사시간의 조건상 적절히 표현하기 어렵다고 생각되어 최종 악기 는 깽과리와 장구로 선정하였다. 검사를 실시하기 전 모든 악기 
의 소리를 두 번씩 들려주어 악기 소리를 익힐 수 있도록 한 후, 서 양 악기 10 개와 국악기 6 개를 2 회 제시하여 총 32 개 문항을 무 작위 순서로 들려주고 해당하는 악기를 선택하도록 구성하였다 (Appendix 1).

\section{감정반응검사}

예비검사는 검사로 사용하기 적절한 곡을 선정하기 위해 시행 하였다. 음악으로 느끼는 감정 카테고리는 기쁨, 슬픔, 분노, 두 려움, 혐오, 놀람, 사랑, 기대감 등 여러 정서가 포함된다. 일반적 으로 사람들에게 음악을 들려준 후 느낀 감정을 표현하도록 한 연구에서 대부분이 행복이나 슬픔과 같은 기본적인 감정들로 표 현하는 반응을 보였고(Gabrielsson \& Juslin, 1996; Haack, 1980), 청각장애가 있을 경우 음악을 듣고 느끼는 감정을 세부 적으로 나누어 선택하기에는 더 어려움이 있을 것으로 생각되어 밝은 감정과 어두운 감정 두 가지의 카테고리로 곡의 감정을 확 인하고자 하였다. 선행 연구에 의하면 밝은 감정의 곡은 빠른 템 포, 큰 피치의 변화, 크지 않은 진폭 변화와 같은 음향학적 특징 을 가지는 반면 어두운 감정의 곡은 느린 템포와 낮은 피치, 불 규칙적인 강도와 같은 특징을 보이는 기준에 의거하여(Scherer \& Oshinsky, 1977), 밝고 어두운 감정의 국악 4곡과 클래식 4곡, 총 16 개 곡을 사용하였다. 연구패널의 논의로 전체 곡 중 해 당 감정이 가장 잘 느껴지는 부분 약 15 초를 자극음으로 제작 하였다. 밝은 감정의 후보곡으로는 국악은 최경만의 '군밤타령' 과 '청춘가', 명상 음악인 '길'과 '정읍사'이며, 클래식은 '쇼팽: 왈 츠 1번 내림 마장조 작품번호 18 화려한 대왈츠(Chopin: Waltz No.1 In E Flat Major Op.18 Grande Valse Brillante)', '조르 주 비제: 카르멘 모음곡 1번 중 투우사의 노래(Georges Bizet: Les Toreadors from Carmen Suite No. 1)', '구노: 아베마리 아(Gounod: Ave Maria)', '랑게: 꽃노래 작품번호 39 (Lange: Blumenlied Op.39)'였다. 어두운 감정의 후보곡으로는 국악은 김성엽의 '능계', 최경만의 '대취타', '수심가', '이별가'이며, 클래 식은 '베토벤: 교향곡 5번 다단조 작품번호 67 운명(Beethoven: Symphony No.5 in C Minor, Op.67 Fate)', '쇼팽: 환상-즉 흥곡 4번 올림 다단조(Chopin: fantasia-impromptu No. 4 in C sharp minor)', '쇼팽: 전주곡 4번 마단조 질식(Chopin: prelude No.4 in E minor Op.28 Suffocation)', '슈베르트: 피아노 3중주 2번 내림 마장조 작품번호 100 D.929- 2악장 안 단테 콘 모토(Schubert: Piano Trio No.2 in E flat, Op.100 D.929- 2. Andante com moto)'였다. 예비검사 결과, $90 \%$ 이 상 동일한 감정에 속한다고 선택된 밝은 감정과 어두운 감정의 국악과 클래식을 각각 2 곡씩, 총 8 개 곡으로 최종 구성하였다. 검사를 실시하기 전 밝고 어두운 감정의 곡을 하나씩 들려주고 연습 기회를 제공하고 무작위 순서로 들려준 후 느껴지는 감정
을 선택하도록 하였다(Appendix 1).

\section{화음지각검사}

화음지각검사와 관련된 선행 연구에서 정상인은 불협화음 정 도를 구분할 수 있었으나 난청인은 불협화음이나 화음의 정도 와 상관없이 모든 제시음을 화음으로 인지한다고 보고하였다 (Caldwell et al., 2016). 음악 전문가와 비전문가 모두 화음으 로 수용하는 정도는 장3화음(Major triad), 단3화음(Minor triad), 감3화음(Diminished triad), 증3화음(Augmented triad) 순이었다. 이를 기반으로 화음과 불협화음의 구별능력 을 확인하는 평가도구를 제작하고자 하였다. 따라서 협화음으 로 가장 잘 인지할 것으로 예상되고 화음의 기본적 형태인 근음 (root or fundamental note)에 장3도음과 완전5도음을 쌍아 만든 장3화음과 가장 불협화음으로 인지할 것으로 예상되는 장 3 화음의 5 음에서 반음이 더 멀어진 증 3 화음을 자극음으로 선 정하였다. Noteworthy composer를 통해 기본 7음계인 C4, $\mathrm{D} 4, \mathrm{E} 4, \mathrm{~F} 4, \mathrm{G} 4, \mathrm{~A} 4, \mathrm{~B} 4$ 에서 3 도씩 겹쳐 올려 형성된 대표 화 음으로 인지되는 장3화음, $\mathrm{C}, \mathrm{D}, \mathrm{E}, \mathrm{F}, \mathrm{G}, \mathrm{A}, \mathrm{B}$ 와 대표 불협화 음으로 인지되는 증3화음, $\mathrm{C}+, \mathrm{D}+, \mathrm{E}+, \mathrm{F}+, \mathrm{G}+, \mathrm{A}+\mathrm{B}+$ 를 120 $\mathrm{bpm}$ 의 빠르기와 1 분음표의 길이로 제작하였다. 화음지각검사 는 7개 코드의 장3화음, 증3화음을 ISI $1,000 \mathrm{~ms}$ 로 무작위 순 서로 들려준 후 화음으로 느껴지는 소리를 선택하도록 하였다. 검사를 실시하기 전 화음으로 느껴지는 소리를 선택하는 두 번 의 연습 기회를 제공하였고 7개 세트(C-C+/D-D+/E-E+/F-F+/ $\mathrm{G}-\mathrm{G}+/ \mathrm{A}-\mathrm{A}+/ \mathrm{B}-\mathrm{B}+$ )를 3회씩 제시하여 총 21문항으로 구성하였 다(Appendix 1).

\section{MMN}

$\mathrm{MMN}$ 을 측정할 때 중요한 것은 피검자가 자극음에 집중하지 않는 것이므로 소리가 들릴 때 마음속으로 빠르게 구구단을 외 우거나 좋아하는 노래를 부르게 하였으며, 반응을 기록하는 동 안에는 깨어 있는 상태에서 한 곳에 시선을 고정하게 하였다. 검 사 전과 검사 중 전극의 저항을 $5 \mathrm{k} \Omega$ 이하가 되도록 점검하였고 자극음을 우측 귀와 좌측 귀 각각 $70 \mathrm{dBnHL}$ 의 강도로 제시하 였다. 기본음(frequent stimulus) $750 \mathrm{~Hz}$ tone burst와 변이 음(infrequent stimulus) $2,000 \mathrm{~Hz}$ tone burst를 총 자극음 중 변이음은 $20 \%$ 의 비율로 구성하여 무작위로 총 50 번 제시하 였다.

\section{MASQ}

선호하는 음악형태와 구성요소, 구체적인 상황별 음악에 대 한 만족도, 음악감상에 대한 태도 및 습관 등을 조사할 수 있고 청각장애인과 정상 청력인의 구체적인 음악감상에 대한 태도 및 
습관을 파악할 수 있는 설문지인 MASQ를 개발하였다. MASQ 는 보편적인 질문으로 구성하여 대상자가 실질적으로 음악을 즐 기기를 원하는지, 선호하는 음악은 무엇인지, 구체적인 상황별로 듣는 음악에 대한 만족도는 어떠한지, 앞으로 즐기기를 원하는 음악의 종류는 무엇인지 등을 파악하여 현재의 음악감상태도와 만족도는 물론 추후 진행할 음악 재활 및 상담자료로도 사용할 수 있도록 하였다. 일반인용인 MASQ_general (MASQ_G)과 청각장애인용인 MASQ_hearing loss (MASQ_H)로 구분하였 으며, 각 문항에 대해 5 개 척도(scale)의 객관식과 주관식으로 응답하도록 구성하였다. MASQ_G는 일상생활 음악감상실태에 대한 8문항, 음악의 특징과 감상 환경에 따른 음악감상 만족도 8 문 항으로 총 16 문항으로 구성하였다. MASQ_H는 MASQ_G의 16 문항에 난청 발생 및 진단 시기, 보장구 종류와 착용 시작 시 기와 같은 난청과 보장구와 관련한 기본 정보와 보장구 착용 후 음악 감상에 대한 만족도 및 음악의 구성요소별 만족도 10문항 을 더 포함하여 총 26문항으로 구성하였다(Table 1, Appendix 2).

\section{RESULTS}

$\mathrm{AMP}$ 검사 결과 피치지각검사에서는 $94.0 \% \pm 6.1 \%$, 멜로디 지각검사에서는 $94.0 \% \pm 7.1 \%$, 리듬지각검사에서는 $99.3 \% \pm$ $1.8 \%$, 음색지각검사에서는 $78.9 \% \pm 41.8 \%$, 감정반응검사에서 는 $96.7 \% \pm 10.4 \%$, 화음지각검사에서는 $85.7 \% \pm 14.1 \%$ 로 모 든 하위 검사의 정답률이 $75 ~ 100 \%$ 에 해당하여 요소별 음악지 각검사로 사용 가능한 것으로 나타났다. 하위검사의 검사음 종 류에 따른 정답률은 다음과 같다.

피치지각검사에서 각 주파수의 정답률은 $262 \mathrm{~Hz}$ 에서 $97.3 \%$ $\pm 16.2 \%, 330 \mathrm{~Hz}$ 에서 $93.3 \% \pm 25.1 \%, 392 \mathrm{~Hz}$ 에서 $88 \% \pm$ $32.7 \%, 1,047 \mathrm{~Hz}$ 에서 $92 \% \pm 27.3 \%, 1,319 \mathrm{~Hz}$ 에서 $94.7 \% \pm$ $22.6 \%, 1,568 \mathrm{~Hz}$ 에서 $98.7 \% \pm 11.5 \%$ 였다. $262,330,392 \mathrm{~Hz}$ 를 포함하는 저주파수 대역과 $1,047,1,319,1,568 \mathrm{~Hz}$ 를 포함하 는 고주파수 대역으로 나누었을 때, $92.9 \% \pm 25.8 \%$ 와 $95.1 \%$ $\pm 21.6 \%$ 의 정답률을 보여 고주파수 대역이 저주파수 대역보다 높은 정답률을 보였으나 통계적으로 유의미한 차이는 보이지 않 았다 $(p>0.05)$.

멜로디지각검사에서 각 멜로디의 정답률은 '고향의 봄'에서 $80.0 \% \pm 40.7 \%$, '까치까치 설날은'에서 $93 \% \pm 25.4 \%$, '나비 야'에서 $93.3 \% \pm 25.4 \%$, '루돌프 사슴코'에서 $93.3 \% \pm 25.4 \%$, '새타령'에서 $96.7 \% \pm 18.3 \%$, '생일축하합니다'에서 $100.0 \% \pm$ 0.0\%, '섬집아기'에서 $100.0 \% \pm 0.0 \%$, '아리랑'에서 $96.7 \% \pm$ $18.3 \%$, '작은별'에서 $100.0 \% \pm 0.0 \%$, '푸른하늘 은하수'에서 $86.7 \% \pm 34.6 \%$ 로 나타났다.

리듬지각검사에서 리듬패턴별 정답률은 리듬패턴 $\mathrm{A}-\mathrm{A}$ 에서 $100.0 \% \pm 0.0 \%, \mathrm{~B}-\mathrm{B}$ 에서 $100.0 \% \pm 0.0 \%, \mathrm{C}-\mathrm{C}$ 에서 $96.7 \%$ $\pm 18.3 \%, \mathrm{D}-\mathrm{D}$ 에서 $100.0 \% \pm 0.0 \%, \mathrm{E}-\mathrm{E}$ 에서 $96.7 \% \pm$ $18.3 \%, \mathrm{~A}-\mathrm{B}$ 에서 $100.0 \% \pm 0.0 \%, \mathrm{~B}-\mathrm{C}$ 에서 $100.0 \% \pm 0.0 \%$, $\mathrm{C}-\mathrm{D}$ 에서 $100.0 \% \pm 0.0 \%, \mathrm{D}$ - $\mathrm{E}$ 에서 $100.0 \% \pm 0.0 \%, \mathrm{E}-\mathrm{A}$ 에서 $100.0 \% \pm 0.0 \%$ 의 정답률을 보였다. 리듬패턴이 동일한지 여부 에 따라 정답률을 비교하였을 때, 동일한 리듬을 확인하는 문제 에서 $98.7 \% \pm 11.5 \%$, 동일하지 않은 리듬을 구별하는 문제에서 $100.0 \% \pm 0.0 \%$ 의 정답률을 보였다.

음색지각검사에서 서양 악기와 국악기의 정답률은 $73.3 \%$ 와 84.4\%였다. 서양 악기 중, 드럼, 기타, 피아노에서 $96.7 \%$ 로 가장 높은 정답률을 보였고, 호른과 플룻에서 $50 \%$ 로 가장 낮 은 정답률을 보였다. 서양 악기 내에서 악기의 정답률은 트롬 본은 $56.7 \% \pm 50.4 \%$, 호른은 $50.0 \% \pm 50.9 \%$, 클라리넷은 $53.3 \% \pm 50.7 \%$, 플룻은 $50.0 \% \pm 50.9 \%$, 바이올린은 $80.0 \%$ $\pm 40.7 \%$, 첼로는 $60.0 \% \pm 49.8 \%$, 드럼은 $96.7 \% \pm 18.3 \%$, 실로폰은 $93.3 \% \pm 25.4 \%$, 기타는 $96.7 \% \pm 18.3 \%$, 피아노 는 $96.7 \% \pm 18.3 \%$ 였다. 국악기 중, 가야금, 꽹과리, 장구에서 $100 \%$ 로 가장 높은 정답률을 보였고, 향피리에서 $36 \%$ 로 가장 낮은 정답률을 보였다. 국악기 내에서 악기의 정답률은 가야금 은 $100.0 \% \pm 0.0 \%$, 해금은 $76.7 \% \pm 43.0 \%$, 대금은 $93.3 \% \pm$ $25.4 \%$, 향피리는 $36.7 \% \pm 49.0 \%$, 꽹과리는 $100.0 \% \pm 0.0 \%$,

Table 1. The composition of the Music Attitudes and Satisfaction Questionnaire (MASQ)

\begin{tabular}{|c|c|c|c|}
\hline \multirow{2}{*}{ Category } & \multirow{2}{*}{ Item } & \multicolumn{2}{|c|}{ Question number } \\
\hline & & MASQ_general & MASQ_hearing loss \\
\hline Individual characteristics & $\begin{array}{l}\text { Basic information about the hearing loss and hearing } \\
\text { assistive device } \\
\text { Satisfaction in listening to music with hearing assistive device } \\
\text { Listening satisfaction by musical components }\end{array}$ & - & $1,2,3,4,5,6,7,8,9,10$ \\
\hline Daily music appreciation & Daily music listening habit & $\begin{array}{c}11,12,13,14,15,16,21 \\
26\end{array}$ & $11,12,13,14,15,16,21,26$ \\
\hline $\begin{array}{l}\text { Music appreciation by } \\
\text { situations }\end{array}$ & $\begin{array}{l}\text { Satisfaction of music appreciation according to music genres } \\
\text { and listening environments }\end{array}$ & $\begin{array}{c}17,18,19,20,22,23,24 \\
25\end{array}$ & $17,18,19,20,22,23,24,25$ \\
\hline
\end{tabular}


장구는 $100.0 \% \pm 0.0 \%$ 였다. 서양 악기와 국악기를 포함한 평 균 정답률은 $78.6 \%$ 였으며 이를 목관 악기, 현악기, 타악기로 구 분하여 분석하였을 때, 목관 악기는 $59.2 \% \pm 49.4 \%$, 현악기는 $79.2 \% \pm 40.8 \%$, 타악기는 $97.5 \% \pm 15.7 \%$ 의 정답률을 보여 타 악기에서 가장 높은 정답률을 보였고 목관 악기에서 가장 낮은 정답률을 보였다 $(p<0.05)$.

감정반응검사에서 감정에 따른 정답률을 비교하였을 때 밝은 감정의 곡과 어두운 감정의 곡에서 모두 $96.7 \% \pm 18.1 \%$ 의 정 답률을 보였으며, 곡의 분류에 따른 정답률을 비교하였을 때 국 악과 클래식에서 $98.3 \% \pm 12.9 \%$ 와 $95.0 \% \pm 22.0 \%$ 의 정답률 을 보여 국악에서 조금 더 높은 수행력을 보였다 $(p>0.05)$. 각 곡의 정답률은 '군밤타령'이 $100.0 \% \pm 0.0 \%$, '청춘가'가 $93.3 \%$ $\pm 25.8 \%$, '대취타'는 $100.0 \% \pm 0.0 \%$, '수심가'는 $100.0 \% \pm$ $0.0 \%$, '쇼팽: 화려한 대왈츠'는 $93.3 \% \pm 25.8 \%$, '비제: 투우사의 노래'는 $100.0 \% \pm 0.0 \%$, '베토벤: 운명'은 $100.0 \% \pm 0.0 \%$, '쇼 팽: 질식'은 $86.7 \% \pm 35.2 \%$ 였다.

화음지각검사에서 음계 $\mathrm{C}, \mathrm{D}, \mathrm{F}$ 를 중심으로 형성된 화음에 서 $88.9 \%$ 로 가장 높은 정답률을 보였고, G에서 $80 \%$ 로 가장 낮 은 정답률을 보였다. 화음에 따라 분석하였을 때, C는 $88.9 \% \pm$ $31.8 \%, \mathrm{D}$ 는 $88.9 \% \pm 31.8 \%, \mathrm{E}$ 는 $86.7 \% \pm 34.4 \%, \mathrm{~F}$ 는 $88.9 \%$ $\pm 31.8 \%, \mathrm{G}$ 는 $84.4 \% \pm 36.7 \%, \mathrm{~A}$ 는 $82.2 \% \pm 38.7 \%, \mathrm{~B}$ 는 $80.0 \% \pm 40.5 \%$ 의 정답률을 보였다.

우측 귀와 좌측 귀에서 측정한 $\mathrm{MMN}$ 파형의 영역에서 유의 미한 차이를 나타내는지 알아보기 위해 대응표본 $t$ 검정을 실시 한 결과, $70 \mathrm{~dB}$ 로 자극음을 제시하였을 때 우측 귀는 $270.52 \pm$ $257.82 \mu \mathrm{V} \cdot \mathrm{ms}$, 좌측 귀는 $280.02 \pm 197.38 \mu \mathrm{V} \cdot \mathrm{ms}$ 로 좌측 귀 의 영역이 더 크게 나타났지만 통계적으로 유의미한 차이는 없는 것으로 나타났다 $(p>0.05)$ (Table 2).

음악감상태도와 만족도는 '음악 감상을 자주 하십니까?'라는 질문에 $80 \%$ 가 '예’라고 응답하였다. '음악을 주로 듣는 시간은 언제입니까?'라는 질문에 $13.3 \%$ 가 ‘휴식 시간 중'에, $40 \%$ 가 ‘대

Table 2. The comparison of onset, peak, and offset latency, amplitude, and area of MMN of right and left ears

\begin{tabular}{|c|c|c|c|c|c|}
\hline & \multicolumn{2}{|c|}{ Average } & \multicolumn{2}{|c|}{ Standard deviation } & \multirow{2}{*}{$p$-value } \\
\hline & Right & Left & Right & Left & \\
\hline \multicolumn{6}{|l|}{ Latency } \\
\hline Onset & 128.67 & 133.94 & 32.02 & 46.86 & 0.670 \\
\hline Peak & 184.43 & 183.83 & 39.61 & 56.30 & 0.960 \\
\hline Offset & 242.27 & 235.84 & 43.52 & 54.30 & 0.552 \\
\hline Amplitude & 2.19 & 2.91 & 1.87 & 2.15 & 0.319 \\
\hline Area & 270.52 & 280.02 & 257.82 & 197.38 & 0.895 \\
\hline
\end{tabular}

MMN: mismatch negativity
중교통 이용 중'에, $6.7 \%$ 가 '집중하는 시간 중'에, $20 \%$ 가 '가벼 운 가사 일을 하는 중'에, $20 \%$ 가 '항상'을 선택하였다. '주로 감 상하는 음악 장르는 어느 것입니까?'라는 질문에 $6.7 \%$ 가 '댄스' 를, $46.7 \%$ 가 '발라드'를, $20 \%$ 가 '힙합\&랩'을, $6.7 \%$ 가 '재즈'를, $13.3 \%$ 가 '클래식'을, $6.7 \%$ 가 '종교음악'을 선택하였다. '노래를 들을 때 선호하는 목소리는 어느 것입니까?'라는 질문에 $33.3 \%$ 가 '여성 노래소리'를, $53.3 \%$ 가 '남성 노래소리'를, $13.3 \%$ 가 '혼 성 노래소리'를 선택하였다. '노래를 들을 때 선호하는 목소리 의 수는 몇 개입니까?'라는 질문에 $53.5 \%$ 가 '독창'을, $33.3 \%$ 가 '2 3인'을, $13.3 \%$ 가 ‘3 5인'을 선택하였다. '5 10인', '10인 이 상 합창'이라고 응답한 비율은 $0 \%$ 였다. '가장 좋아하는 악기 소 리는 무엇입니까?'라는 질문에 $50.0 \%$ 가 '피아노'를, $22.2 \%$ 가 '기 타'를, $16.7 \%$ 가 ‘드럼'을, $5.6 \%$ 가 ‘바이올린'을, $5.6 \%$ 가 ‘플룻’이 라고 응답하였다. '음악을 들을 때 선호하는 악기의 수는 몇 개입 니까?'라는 질문에 ' 1 개의 악기'가 $0 \%$, ' 2 3개의 악기'가 $33.3 \%$, '3 5개의 악기'가 $40 \%$, ' 10 개 이상의 악기'가 20\%, '5 10개의 악기'가 $6.7 \%$ 로 나타났다. 음악의 특징과 감상 환경에 따른 음악 감상 만족도에 대한 내용을 질문하였을 때, $67.5 \% \pm 36.9 \%$ 가 '매우 만족' 혹은 '만족'이라고 응답하였다. 문항들을 구체적으 로 살펴보면, 연주해 본 적이 있는 악기로 연주되거나 친숙한 악 기로 연주된 음악을 들을 때 $33.3 \%$ 가 '매우 만족', $46.7 \%$ 가 '만 족, $20 \%$ 는 “보통’이라고 응답하였다. 일상에서 자주 접하거나 친 숙한 음악을 들을 때 $33.3 \%$ 가 '매우 만족, $60 \%$ 가 '만족', $6.7 \%$ 가 “보통’이라고 응답하였다. 반면 연주해 본 적이 없는 악기로 연 주되거나 생소한 악기로 연주된 음악을 들을 때 $40 \%$ 가 '만족, $53.3 \%$ 가 ‘보통', $6.7 \%$ 가 ‘불만족’이라고 응답하였다. 일상에서 접 해보지 못하였거나 낯선 음악을 들을 때는 $20 \%$ 가 '만족', $66.7 \%$ 가 ‘보통', $13.3 \%$ 가 ‘불만족’이라고 응답하였다. 조용한 곳에서 음악을 들을 때는 $46.7 \%$ 가 '매우 만족', $53.3 \%$ 가 '만족'이라고 응답하였다. 반면 주위에서 다양한 소리가 날 때 듣는 음악에 대 해서는 $13.3 \%$ 가 '만족', $60 \%$ 가 '보통', $20 \%$ 가 ‘불만족', $6.7 \%$ 가 '매우 불만족'이라고 응답하였다. 라이브로 연주되는 음악을 직 접 들을 때 $60 \%$ 가 '매우 만족', $40 \%$ 가 '만족'이라고 응답하여 만 족도가 꽤 높은 것으로 나타났다. 반면 녹음된 음악을 전자기기 나 핸드폰을 통해 들을 때는 $26.7 \%$ 가 '매우 만족', $66.7 \%$ 가 '만 족, $6.7 \%$ 가 '보통’이라고 응답하였다. 앞으로 음악감상을 자주 할 계획이 있는지에 대해서는 $100 \%$ 가 그렇다고 응답하여 음악 감상의 높은 욕구를 표현하였다.

\section{DISCUSSIONS}

$\mathrm{AMP}$ 를 통한 정상 청력인의 음악지각능력검사 결과, 음색지각 검사는 다른 검사와 비교하였을 때 수행력이 비교적 낮게 나타 
났다. 이러한 경향은 다른 선행 연구에서도 찾아볼 수 있었는데 이는 일반적으로 대상자들이 아동기에 다양한 악기에 노출된 경 험이 적기 때문으로 생각된다고 연구자는 보고하였다(Jung et al., 2010). 음색지각능력은 악기의 고유한 소리 특징과 그를 확 인하는 음악적 경험에 따라 달라지기 때문인 것으로 분석하였다. 화음지각검사는 음계 C를 중심으로 형성된 화음에서 $88.9 \%, \mathrm{G}$ 에서 $80 \%$ 의 정답률을 보여 음이 낮아질수록 정답률이 낮아지 는 경향을 보였다.

음악지각능력과 $\mathrm{MMN}$ 반응의 관계에 관한 연구에는 자극 음 조건을 다양하게 하거나 음악훈련 집단과 비훈련 집단을 대 상으로 하는 등 다양하게 실시되었다. $\mathrm{MMN}$ 반응은 측정 방법 과 자극음 종류에 따라 달라지고 선행 연구(Kim et al., 2006; Schwade et al., 2017)에서 정상인의 반응이 각기 다르게 보 고되고 있어 정상 반응을 참고할 수 있는 기준이 제한적이다. 본 연구와 자극음이 유사한 $1,000 \mathrm{~Hz}$ 의 기본음과 $2,000 \mathrm{~Hz}$ 의 변 이음 tone burst자극음으로 정상 성인에게 측정한 연구에서 $150.70 \sim 184.00 \mathrm{~ms}$ 범위의 잠복기와 $1.44 \sim 3.55 \mu \mathrm{V}$ 의 진폭을 보고하였다(Brossi et al., 2007). 본 연구에서도 우측과 좌측 귀에서 잠복기가 $184.43 \mathrm{~ms}$ 와 $183.83 \mathrm{~ms}$ 였고 진폭이 $2.19 \mu \mathrm{V}$ 와 $2.91 \mu \mathrm{V}$ 로 유사한 자극음에서 나타나는 정상 성인의 결과와 매우 근접한 반응이었다. 그러나 추후 연구에서는 정상 청력과 청각장애인 그룹의 음악에 대한 뇌 인지 반응을 비교하기 위하 여 청각장애 그룹의 $\mathrm{MMN}$ 반응 분석이 필요할 것으로 생각된다. 또한 연령별로 청년과 중년을 구분하고, 음악지각평가에 적절한 자극음을 기본음과 변이음으로 제시한 $\mathrm{MMN}$ 연구는 우리의 음 악분석능력을 구체적으로 평가하는 데 도움이 될 것으로 생각한 다.

$\mathrm{AMP}$ 검사도구의 특성은 피치지각검사는 저주파수 대역보 다 고주파수 대역에서 $92.9 \% \pm 25.8 \%$ 와 $95.1 \% \pm 21.6 \%$ 로 고 주파수 대역을 더 잘 지각하였고, 멜로디지각검사는 $94.0 \% \pm$ $7.1 \%$ 로 비교적 높은 수행력을 보였고, 리듬지각검사는 모든 검 사들 중 $99.3 \% \pm 1.8 \%$ 로 가장 높은 수행력을 보였고, 음색지각 검사는 $78.9 \% \pm 41.8 \%$ 로 다른 검사들보다 낮게 나타났지만 서 양 악기는 $73.3 \%$, 국악기는 $84.4 \%$ 로 국악기에서 $11.1 \%$ 더 높 은 수행력을 보였고, 감정반응검사는 밝은 감정과 어두운 감정의 곡 모두 $96.7 \% \pm 18.1 \%$ 로 높은 수행력을 보였고, 화음지각검사 는 $85.7 \% \pm 14.1 \%$ 로 비교적 낮은 수행력을 보였다. 정리하자면 요소별 음악지각의 수행력은 리듬이 가장 높은 수행력을 보였고 이후, 감정반응, 피치와 멜로디, 화음, 음색지각검사 순으로 수행 력이 낮아졌다. 그러나 음색지각검사에서는 국악기에서 더 높은 수행력을 보여 국악기를 포함한 AMP검사는 한국인의 정서와 문화가 반영된 검사로 생각할 수 있다.

현재까지 음악지각능력을 구체적으로 평가할 수 있는 도구가
없어 정상 및 청력손실 그룹의 음악지각능력에 대한 평가에 한 계가 있었다. 따라서 본 연구는 한국인의 정서와 문화를 반영한 $\mathrm{AMP}$ 를 개발하고 정상 청력인의 정답률을 분석하여 음악지각 검사로서의 적용 가능성을 확인하고자 하였다. 음악요소별 여섯 개의 음악지각검사에서 평균 정답률은 $91.4 \%$ 로 정상 그룹의 음 악지각능력을 총괄적으로 평가할 수 있는 점을 확인하였다. 그 러나 청각장애 그룹에 적용할 수 있는 검사도구 인지에 대한 분 석은 직접 검사를 실시한 후 결정할 수 있을 것으로 생각한다. 본 검사에서 $\mathrm{MMN}$ 검사와 $\mathrm{MASQ}$ 작성시간을 제외한 $\mathrm{AMP}$ 의 검사 소요시간은 약 30 분이 소요되었고 짧은 검사시간이 장점이다. 더 나아가 보청기와 인공와우 착용자 등 청력손실이 있는 그룹 을 대상으로 $\mathrm{AMP}$ 검사를 실시하여 정상 그룹의 결과와 비교하 면 청각장애 대상으로 구체적인 검사도구를 활용할 수 있고, 성 공적인 음악지각능력 평가를 토대로 청력손실 그룹의 음악지각 능력을 향상시킬 수 있는 방법을 구현하는 음악 재활 자료도 개 발할 수 있을 것이다.

중심 단어: 음악지각검사, 피치지각검사, 멜로디지각검사, 음색 지각검사, 음전위 부정합.

\section{Ethical Statement}

This study was approved by the Institutional Review Board of Hallym University (HIRB-2019-070).

\section{Acknowledgments}

N/A

\section{Declaration of Conflicting Interests}

There is no conflict of interests.

\section{Funding}

This work was supported by the Ministry of Education of the Republic of Korea and the National Research Foundation of Korea (NRF-2020S1A5A2A01044374).

\section{Author contributions}

Conceptualization: Jinsook Kim, Jeong-Sug Kyong. Data curation: Yerim Shin, Jiyeong Yun, Sungmin Jo. Formal analysis: Yerim Shin, Jiyeong Yun, Sungmin Jo. Funding acquisition: Jinsook Kim. Investigation: Jinsook Kim. Methodology: Jinsook Kim, Yerim Shin, Jiyeong Yun. Project administration: Jinsook Kim, Jeong-Sug Kyong. Resources: Jinsook Kim, JeongSug Kyong. Software: Yerim Shin, Jiyeong Yun, Sungmin Jo. 
Supervision: Jinsook Kim, Jeong-Sug Kyong. Validation: Yerim Shin, Sungmin Jo. Visualization: Jinsook Kim, Yerim Shin, Jiyeong Yun, Sungmin Jo. Writing_original draft: Yerim Shin, Jiyeong Yun. Writing—review \& editing: Jinsook Kim, Yerim Shin, Jiyeong Yun, Sungmin Jo.

\section{ORCIDiD}

Yerim Shin https://orcid.org/0000-0002-2914-6711

Jiyeong Yun https://orcid.org/0000-0002-5561-3205

Jeong-Sug Kyong https://orcid.org/0000-0003-0798-0059

Sungmin Jo https://orcid.org/0000-0002-6388-2114

Jinsook Kim https://orcid.org/0000-0003-3440-2393

\section{REFERENCES}

Brockmeier, S. J. (2000). Munich Music Questionnaire (MUMU). MEDEL GmbH. Retrieved from https://www.medel.com/support/rehab/ rehabilitation-downloads.

Brossi, A. B., Borba, K. C., Garcia, C. F. D., Reis, A. C. M. B., \& Isaac, M. D. L. (2007). Verificação das respostas do mismatch negativity (MMN) em sujeitos adultos normais. Revista Brasileira de Otorrinolaringologia, 73, 793-802.

Caldwell, M. T., Jiradejvong, P., \& Limb, C. J. (2016). Impaired perception of sensory consonance and dissonance in cochlear implant users. Otology and Neurotology, 37(3), 229-234.

Chin, T. \& Rickard, N. S. (2012). The music USE (MUSE) questionnaire: An instrument to measure engagement in music. Music Perception, 29(4), 429-446.

Fitzgerald, D., Fitzgerald, H., Brockmeier, S. J., Searle, O., Grebenev, L., \& Nopp, P. (2006). Musical Sounds in Cochlear Implants (MuSIC) Test. Innsbruck: MED-EL.

Fujioka, T., Trainor, L. J., Ross, B., Kakigi, R., \& Pantev, C. (2004). Musical training enhances automatic encoding of melodic contour and interval structure. Journal of Cognitive Neuroscience, 16(6), 10101021.

Fujioka, T., Trainor, L. J., Ross, B., Kakigi, R., \& Pantev, C. (2005). Automatic encoding of polyphonic melodies in musicians and nonmusicians. Journal of Cognitive Neuroscience, 17(10), 1578-1592.

Gabrielsson, A. \& Juslin, P. N. (1996). Emotional expression in music performance: Between the performer's intention and the listener's experience. Psychology of Music, 24(1), 68-91.

Gordon, E. (1967). The musical aptitude profile. Music Educators Journal, 53(6), 52-54.

Gordon, E. E. (1979). Developmental music aptitude as measured by the Primary Measures of Music Audiation. Psychology of Music, 7(1), 42-49.

Gottselig, J. M. (2001). Human Neuroanatomical Systems for Perceiving Emotion in Music. Ann Arbor: The University of Lowa.

Haack, P. A. (1980). The behavior of music listeners. In Hodges, D. Handbook of Music Psychology (pp.141-182). Lawrence, KS: National Association for Music Therapy.

Han, D. W. (1991). Encyclopedia of Korean National Culture. Seongnam: The Academy of Korean Studies.
Hyun, K. S. (2000). A study of development of Korean Music Aptitude Test. Korean Music Education, 18, 403-440.

Jeong, M. R. \& Lee, D. (2012). A case study on music perception ability of children with cochlear implants. Journal of Speech-language and Hearing Disorders, 21(2), 209-226.

Jung, K. H., Cho, Y. S., Cho, J. K., Park, G. Y., Kim, E. Y., Hong, S. H., et al. (2010). Clinical assessment of music perception in Korean cochlear implant listeners. Acta Oto-laryngologica, 130(6), 716-723.

Kang, R., Nimmons, G. L., Drennan, W., Longnion, J., Ruffin, C., Nie, K., et al. (2009). Development and validation of the University of Washington Clinical Assessment of Music Perception test. Ear and Hearing, 30(4), 411-418.

Kim, L. S., Kim, B. Y., Kim, C. G., Lee, S. H., Jung, S. W., \& Kim, J. R. (2006). Mismatch negativity according to the changes of auditory stimuli. Korean Journal of Otolaryngology-Head and Neck Surgery, 49(12), 1151-1158.

Koelsch, S., Schröger, E., \& Tervaniemi, M. (1999). Superior pre-attentive auditory processing in musicians. Neuroreport, 10(6), 13091313.

Kwon, E. Y. (2019). Cochlear implanted teenagers' musical satisfaction related with their music education and activity (Unpublished master's thesis). Seoul: Ehwa Womans University.

Lee, S. W. (2013). Perception and Recognition of Music I. Seoul: EUMAKSEKEY.

Looi, V., McDermott, H., McKay, C., \& Hickson, L. (2008). Music perception of cochlear implant users compared with that of hearing aid users. Ear and Hearing, 29(3), 421-434.

Moore, B. C. (2008). The role of temporal fine structure processing in pitch perception, masking, and speech perception for normal-hearing and hearing-impaired people. Journal of the Association for Research in Otolaryngology, 9(4), 399-406.

Roy, A. T., Scattergood-Keepper, L., Carver, C., Jiradejvong, P., Butler, C., \& Limb, C. J. (2014). Evaluation of a test battery to assess perception of music in children with cochlear implants. JAMA Otolaryngology--Head and Neck Surgery, 140(6), 540-547.

Ryu, K. B. (2014). A study on music preferences and activities of Korean middle and high school students (Unpublished master's thesis). Seoul: Ehwa Womans University.

Sandmann, P., Kegel, A., Eichele, T., Dillier, N., Lai, W., Bendixen, A., et al. (2010). Neurophysiological evidence of impaired musical sound perception in cochlear-implant users. Clinical Neurophysiology, 121(12), 2070-2082.

Scherer, K. R. \& Oshinsky, J. S. (1977). Cue utilization in emotion attribution from auditory stimuli. Motivation and Emotion, 1(4), 331346.

Schwade, L. F., Didoné, D. D., \& Sleifer, P. (2017). Auditory evoked potential mismatch negativity in normal-hearing adults. International Archives of Otorhinolaryngology, 21(3), 232-238.

Sim, S. T. (1996). Dictionary of Musical Terms. Seoul: Modern Music Publisher.

Tervaniemi, M., Just, V., Koelsch, S., Widmann, A., \& Schröger, E. (2005). Pitch discrimination accuracy in musicians vs nonmusicians: An event-related potential and behavioral study. Experimental Brain Research, 161(1), 1-10.

Trainor, L. J., McDonald, K. L., \& Alain, C. (2002). Automatic and controlled processing of melodic contour and interval information measured by electrical brain activity. Journal of Cognitive Neuroscience, 14(3), 430-442.

Uys, M. \& van Dijk, C. (2011). Development of a music perception test 
for adult hearing-aid users. The South African Journal of Communication Disorders, 58(1), 19-47.

Van Zuijen, T. L., Sussman, E., Winkler, I., Näätänen, R., \& Tervaniemi, M. (2005). Auditory organization of sound sequences by a temporal or numerical regularity--a mismatch negativity study comparing musicians and non-musicians. Cognitive Brain Research, 23(2-3), 270-276.

Yoon, G. M., Kim, S. H., Cho, E. A., \& Goo, H. Y. (2006). Music Theory for Arts High School. Seoul: Modern Music Publisher. 


\section{APPENDIX}

Appendix 1. The composition of the Assessment of Music Perception (AMP) test

\begin{tabular}{cccc} 
1. Pitch perception test & $\mathrm{C} 4,262 \mathrm{~Hz}$ & $\mathrm{E} 4,330 \mathrm{~Hz}$ & $\mathrm{G} 4,392 \mathrm{~Hz}$ \\
\hline $\begin{array}{c}\text { Low } \\
\text { frequency }\end{array}$ & $\mathrm{C} 6,1047 \mathrm{~Hz}$ & $\mathrm{E} 6,1319 \mathrm{~Hz}$ & $\mathrm{G}$ \\
\hline & &
\end{tabular}

3. Rhythm perception test

2. Melody perception test

Name of the melody

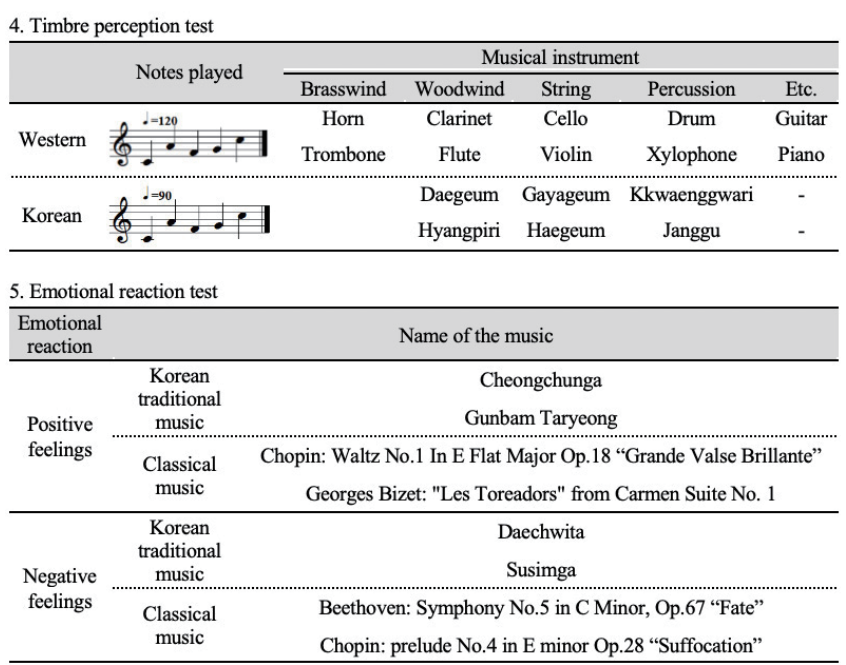

\begin{tabular}{|c|c|c|c|c|c|c|c|}
\hline Triad & $\mathrm{C}$ & D & $\mathrm{E}$ & $\mathrm{F}$ & G & A & B \\
\hline $\begin{array}{c}\text { Major } \\
\text { (Consonance) }\end{array}$ & $\frac{6}{8}$ & $\frac{6}{9=8}$ & $\frac{b}{9}$ & 68 & $\frac{6}{8}$ & $\frac{6}{g}=8$ & $\frac{6}{9}$ \\
\hline $\begin{array}{l}\text { Augmented } \\
\text { (Dissonance) }\end{array}$ & ta & $6+8$ & $6+8$ & 6 & $6=8$ & $b \# 8$ & $b^{4}=$ \\
\hline
\end{tabular}




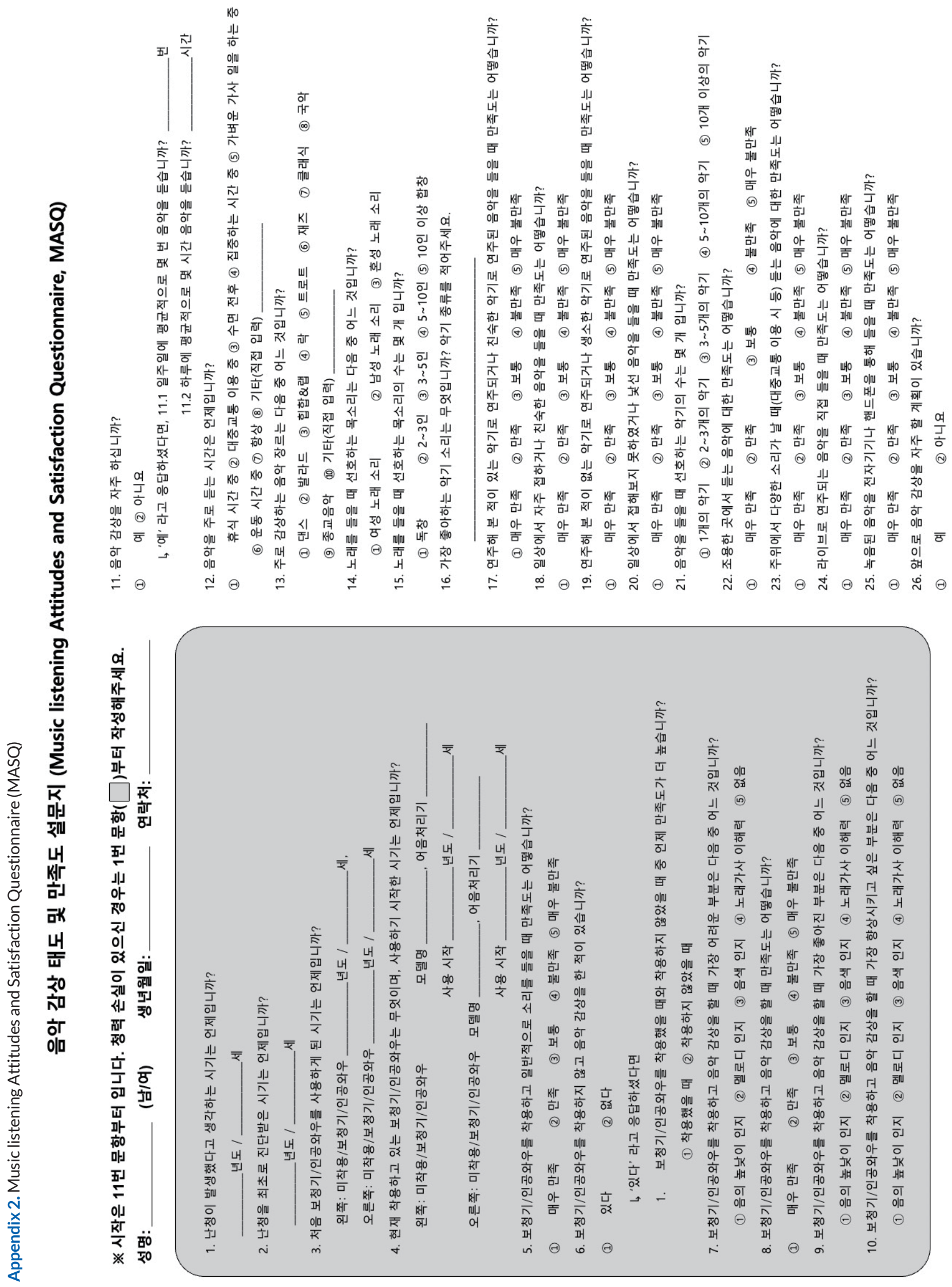

